Toward an alternative community-driven restorative model of school discipline

A report by

Johanne Jean-Pierre, Ph.D.

Assistant Professor

School of Child and Youth Care, Ryerson University

Jessica T. Bundy, M.A.

$\mathrm{Ph} . \mathrm{D}$. candidate

Centre for Criminology \& Sociolegal Studies, University of Toronto

December 2021 
Toward an alternative community-driven restorative model of school discipline

Report prepared by Dr. Johanne Jean-Pierre and Jessica T. Bundy

ISBN: 978-1-77417-035-9

(C) Copyright is shared between the authors and Ryerson University, 2021.

Quotation with appropriate credit and referencing is permissible. 


\section{Toward an alternative community-driven restorative model of school discipline}

(C) Copyright is shared between the authors and Ryerson University, Toronto, 2021.

ISBN: 978-1-77417-035-9

\section{Authors}

Johanne Jean-Pierre, Ph.D., Principal Investigator

Assistant Professor, School of Child and Youth Care, Ryerson University

Jessica T. Bundy, M.A., Research Assistant

Ph.D. candidate, Centre for Criminology \& Sociolegal Studies, University of Toronto

\section{Keywords:}

1. African Nova Scotians, African Canadians, Black Canadians

2. Canada, Atlantic Canada, Maritimes, Nova Scotia

3. Children and youth, student well-being

4. Diversity, equity, and inclusion in education

5. Restorative justice and practices in education

6. Code of conduct, classroom management, school environment, and school climate

7. School discipline models, interventions, practices, and policy

8. School discipline racial disproportionality, racial discrimination, and anti-Black racism

The views expressed in this report are those of the authors and do not necessarily represent the views of Ryerson University or the University of Toronto.

\section{Suggested citation formats:}

American Psychological Association (APA) $7^{\text {th }}$ edition:

Jean-Pierre, J., \& Bundy, J.T. (2020). Toward a community-driven restorative model of school discipline. Ryerson University.

American Sociological Association (ASA) $4^{\text {th }}$ edition:

Jean-Pierre, Johanne, and Jessica T. Bundy. 2020. Toward a community-driven restorative model of school discipline. Toronto: Ryerson University. 
Table of Contents

\begin{tabular}{|l|l|}
\hline Acknowledgements & 4 \\
\hline Executive summary & 5 \\
\hline Introduction & 6 \\
\hline Literature review & 6 \\
\hline Overview of recommendations pertaining to alternative disciplinary measures & 7 \\
\hline The significant role of student support workers & 8 \\
\hline Nova Scotia school discipline guidelines & 9 \\
\hline Alternative school discipline interventions and models in the literature & 11 \\
\hline Methodology & 15 \\
\hline Results & 16 \\
\hline $\begin{array}{l}\text { Preconditions and sustainable implementation of alternative non-punitive } \\
\text { interventions }\end{array}$ & 17 \\
\hline $\begin{array}{l}\text { A cultural organizational shift: the overhaul of curricular and pedagogical } \\
\text { practices }\end{array}$ & 19 \\
\hline Conclusion & 21 \\
\hline Recommendations & 23 \\
\hline Overall recommendations & 23 \\
\hline Recommendations from community forum & 25 \\
\hline References & 26 \\
\hline
\end{tabular}

Table of Figures and Tables

\begin{tabular}{|l|l|}
\hline Figure 1 Provincial guiding principles to respond to an unacceptable behaviour & 10 \\
\hline $\begin{array}{l}\text { Figure 2 Common principles of alternative non-punitive disciplinary interventions and } \\
\text { model }\end{array}$ & 11 \\
\hline Figure 3 Two categories of alternative non-punitive practices of school discipline & 12 \\
\hline Figure 4 Alternative individualized interventions of school discipline & 13 \\
\hline Figure 5 Alternative school-wide models of school discipline & 15 \\
\hline Figure 6 Major themes of the findings of the study & 17 \\
\hline Figure 7 Essential preconditions & 17 \\
\hline $\begin{array}{l}\text { Figure 8 Participants' views about school personnel's role for a cultural organizational } \\
\text { shift }\end{array}$ & 20 \\
\hline Table 1 School professionals' responsibility regarding discipline & 9 \\
\hline Table 2 Participants' age group and self-identified origin & 16 \\
\hline Table 3 Participants' gender and language & 16 \\
\hline
\end{tabular}

Toward an alternative community-driven restorative model of school discipline 


\section{Acknowledgements}

We want to express our thanks and gratitude to the participants of this study who generously shared their time and knowledge. Your insights have been instrumental to the preparation of this report and to reframe discussions around school discipline.

We acknowledge that this research project took place on the ancestral and traditional territory of the Mi'kmaq people. We are grateful for their welcome and ongoing care of the lands and waters.

This report draws on research funded by a 2018-2019 Ryerson University Faculty of Community Services Seed Grant, a 2019-2020 institutional Social Sciences and Humanities Research Council (SSHRC) Explore Grant, and a 2020 Ryerson University Office of the Vice-President, Research \& Innovation (OVPRI) Internal Scholarly, Research and Creative Events/Activities Supplemental Funds Grant. 


\section{Executive summary}

Given that education is a fundamental human right, a vehicle for social mobility, and a determinant of employability and lifetime earnings, several stakeholders are invested in addressing barriers to learning, especially among historically marginalized and underserved populations. Black learners in Nova Scotia are disproportionately affected by punitive school discipline, such as out-of-school suspensions, which constitutes a barrier to accessing learning opportunities. In fact, there is strong evidence in the existing literature that punitive school discipline has detrimental short- and longterm effects on students. Drawing from data collected during a research project, this report presents key findings and policy recommendations to address school discipline racial disproportionality, to better support Black learners' educational pathways, and to achieve equitable and inclusive education.

This qualitative study involved nine focus groups and 17 interviews with 60 participants between 2018 and 2019 in English and in French. During a community forum held in Halifax on March $12^{\text {th }} 2020$ to present preliminary findings, attendees provided additional insights that greatly overlap with the main findings of the study, and which are also shared. Black learners, parents, and community members were asked about their experiences of school discipline and promising interventions and practices. The findings indicate that participants believe that alternative nonpunitive practices, particularly restorative practices in education, should be implemented and accompanied with an organizational cultural shift to create equitable learning environments for all, including Black learners. Participants suggest that the adoption of a restorative model of school discipline, applied consistently in a fair and transparent fashion in a caring and nurturing school environment, can simultaneously address school discipline racial disproportionality and educational outcomes. They also insist that an organizational cultural shift is necessary to overhaul existing curricular and pedagogical practices. This requires school personnel to work in synergy towards the adoption of culturally relevant and sustaining pedagogy, and effective strategies to support students with disabilities and the development of relationships with parents and community members. Although some institutional changes have been implemented since the 1994 Black Report on Education was published, the main findings point to persistent institutional gaps.

Overall, we reiterate an important recommendation made in the Black Report on Education, which stated that any new or revised educational policy, legislation, or training should integrate the input of Black community members, parents, and youth. For instance, we recommend revisions to the provincial School Code of Conduct Policy for a better definition of misconduct, and an emphasis on non-punitive school discipline approaches, including a restorative model. To address the disproportionate number of Black students suspended, we recommend a community-driven restorative justice model of school discipline co-designed, co-implemented, and co-monitored with Black community organizations and advocates. We also recommend the creation of a school committee whose mandate is to monitor the nature and responses to misconduct incidents to identify service gaps, school climate issues, and students' needs. In conjunction with these practices, we strongly encourage school personnel to develop and establish positive relationships with students to create caring and nurturing learning environments. We contend that such recommendations will promote Black learners' development, well-being, and academic success

Toward an alternative community-driven restorative model of school discipline 


\section{Introduction}

Education is concomitantly a path for self-actualization and personal growth, a mechanism of social mobility, a crucial factor of labour market outcomes and lifetime earnings, a social determinant of health and quality of life, a fundamental institution in a democratic society, and a human right. Because education is so consequential at the individual and societal levels, barriers to it are a cause of great concern for various stakeholders, including parents, students, and community advocates. As a case in point, several advocates have identified issues pertaining to school discipline processes and outcomes in Nova Scotia (Barjun Consultants, 2001; Black Learners Advisory Committee, 1994; Nunn, 2006). Recently, we learned that Black learners in Nova Scotia are more likely to be subjected to out-of-school suspensions than other students across the province (Woodbury, 2016). Yet, scholarly literature indicates that punitive school discipline, such as out-of-school suspensions, are ineffective, worsen problematic behaviour, alienate students from school, and keep students away from formal learning opportunities (Fenning et al., 2004; Gregory et al., 2010; Jean-Pierre \& Parris-Drummond, 2018; Mayer, 2001; Noguera, 2003).

This report is based on the main findings of a qualitative study that aimed to address school discipline racial disproportionality in Nova Scotia, conceive an alternative model of school discipline, and promote the academic success of Black learners. A research project was conducted with African Nova Scotian and Black immigrant youth, parents, and community members across the province between 2018 and 2019 in both English and French. Through nine focus groups and 17 interviews, 60 members of the community provided their perspectives and insights to inform the conception of an alternative model of school discipline. A community forum subsequently took place in March 2020 to discuss the findings and main recommendations with community members. Based on the research project and scholarly literature, this report presents key findings and recommendations that can foreground future school discipline policy and interventions to further Black learners' academic success in Nova Scotia. Overall, the key themes derived from participants' narratives emphasize the need to adopt alternative non-punitive responses to misconduct - primarily a restorative model — while simultaneously enhancing inclusive curricular and pedagogical practices to foster Black students' academic success.

\section{Literature review}

With 400 years of presence, Black people in Nova Scotia constitute the largest visible minority in the province, with a total population of 22,000 (African Nova Scotian Affairs, 2020; Statistics Canada, 2017). School segregation existed in Nova Scotia de facto from 1811 to 1865, and de jure from 1865 to 1954, with the last segregated school closing in 1984 (Saney, 1998). African Nova Scotian children and youth faced major barriers to accessing education during and after school segregation (Black Learners Advisory Committee, 1994; Pachai \& Bishop, 2006). Today, certain educational barriers remain, and are compounded by other forms of social inequality. Indeed, Black people in Nova Scotia are still marginalized by environmental racism (Waldron, 2018), the lack of information available on, and awareness of, specific healthcare services (Maddalena et al., 2013), the injustices experienced with law enforcement and the criminal justice system (Bundy, 2019; Williams, 2013; Wortley, 2019), and the impact of racism on everyday life (Beagan \& Etowa, 2009). Hence, historical, racist customs and laws and contemporary systemic racism negatively affect many aspects of daily life, including education. Compared to the rest of the province's citizenry, African Nova Scotians are less likely to finish

Toward an alternative community-driven restorative model of school discipline 
high school (77.7\% vs $85.3 \%$ ) or have a university degree (18\% vs $22 \%$ ) (African Nova Scotian Affairs, 2020). Participants in scholarly studies have also expressed concerns that Black students were treated unfairly, and were disciplined more quickly and severely, in comparison to their classmates in Nova Scotia and the rest of Canada (Beagan \& Etowa, 2009; James et al., 2010; Sibblis 2014). In many reports, recommendations related to school discipline have been put forward, several of which will be reviewed below (Barjun Consultants, 2001; Black Learners Advisory Committee, 1994; Lee \& Marshall, 2009; Nunn, 2016).

\section{Overview of recommendations pertaining to alternative disciplinary measures}

The 1994 Black Learner's Advisory Committee's (BLAC) Report on Education examined African Nova Scotian learners' experiences, challenges, and possible pathways for success, and has been foundational in spearheading some policy initiatives. In relation to school discipline, the Committee (1994) recommended: a) the implementation of alternative school discipline practices in lieu of punitive interventions; b) the development of a collaborative relationship between school administrators and the community to resolve discipline incidents; and c) the presence of student support workers (SSW) to support Black learners. Unfortunately, the first two formal suggestions were not fully implemented, and though the African Nova Scotian student support workers program is valuable, some adjustments are warranted (Lee \& Marshall, 2009).

School and school boards should: "collaborate with communities in resolving disciplinary problems. Meet with community groups to discuss and lay out a strategy to improve discipline and learn the reasons why the child/student is acting up as a first step to formulating a strategy to prevent it. Teachers must be fair but firm, more welcoming and accessible to parents and students. Develop effective and alternative disciplinary programs and practices in place of out of school suspensions. These may take the form of short-term crisis intervention programs or in-school suspension models that have proven to educationally and behaviourally successful" (Black Learners Advisory Committee, Volume 3, 1994, p. 95).

In addition to the BLAC report (1994), The African Nova Scotian Education Summit Final Report reiterated the need to develop alternative non-punitive practices to respond to misconduct.

"Develop alternative discipline measures to help students understand the choices they are making ant eh consequences of those choices" (Barjun Consultants, 2001, p. 87).

In 2004, following the killing of Theresa McEvoy by a young offender who had been released two days prior, a public inquiry investigated the handling of this young offender to learn from the tragedy. This inquiry resulted in a report that touched upon gaps and failings in the criminal justice and education systems. Interestingly, recommendation 34 of the Report of the Nunn Commission of Inquiry denoted the pertinence of alternative disciplinary measures for all students across the province, with an acknowledgement that moving students away from formal learning opportunities is harmful and ineffective (Nunn, 2016).

"The Department of Education, in conjunction with the province's strategy for children and youth at risk, should provide Nova Scotia schools with adequate space, staff, and programs for in-school alternatives to out-of-school suspension as a disciplinary measure" (Nunn, 2016, p. 282).

Toward an alternative community-driven restorative model of school discipline 
Several studies point to the potential of a positive school-family and school-community relationship to promote a positive racial identity and academic success among Black students (Codjoe, 2007; Livingstone et al., 2014; Malinen \& Robert-Jeffers, 2019). In the past, education advocates recommended that school administrators and teachers work with the community to conceive alternative disciplinary measures, and the government initially committed to work with the Nova Scotia School Board Association to establish the best path forward to accomplish this goal (BLAC Implementation Review Committee, 2003; Black Learners Advisory Committee, 1994). However, the collaborative adoption and implementation of alternative disciplinary interventions with African Nova Scotian community members remains unfulfilled, and should be considered (BLAC Implementation Review Committee, 2003).

\section{The significant role of student support workers}

Although the elaboration and development of alternative school discipline interventions in collaboration with the Black community has not yet materialized, the recommended Student Support Worker (SSW) program exists today. Using a culturally relevant approach, and the acute knowledge and understanding of Black communities, African Nova Scotian student support workers - in collaboration with teachers and other school professionals - build relationships with Black students to support their development and well-being. Their presence is an asset in the school system, as they "maintain contact, share information, and transfer skills to many African Canadian families" (BLAC Implementation Review Committee, 2003, p.18). In 2003, there were 21 African Nova Scotian student support workers across the province, and given the benefits of their presence, increasing the number of student support workers to 75 was recommended (BLAC Implementation Review Committee, 2003). A subsequent report would reiterate the value of the student support workers' program, propose the expansion of the program, and point to required improvements to the organization of their daily work to strengthen African Nova Scotian student support workers' contribution in schools (Lee \& Marshall, 2009).

There are three main issues regarding student support workers' working conditions and environment that should be underscored, because they are linked to school discipline processes. First, Lee and Marshall (2009) noted that school teachers and administrators could act as though Black learners were the sole responsibility of their community or Black school employees. This should be taken into account, because when teachers take responsibility for their students, they are more likely to adopt a caring and supportive relationship with each one of them, and this in turn results in a positive school climate (Olley et al., 2010). School administrators should reinforce the principle that even when there is an African Nova Scotian student worker in the school, all teachers remain responsible for Black students' academic success and well-being. Second, Lee and Marshall (2009) indicated that a heavy case load, combined in some instances with the requirement to travel to multiple schools, limited the presence of student support workers to one or two days in each school. This scheduling arrangement inhibited student support workers' ability to effectively maintain relationships with students and provide direct social-emotional support. Third, African Nova Scotian student support workers shared that, when incidents of misconduct occur, they would prefer to be involved in meetings with parents and school discipline decision-making processes before consequences are implemented. Unfortunately, they were often contacted and informed of disciplinary action late, after the meetings and decision-making processes had already taken place. Given their pre-existing relationships with students and parents, school administrators and teachers should value and tap into African Nova Scotian student support workers' critical insights to address misconduct.

Toward an alternative community-driven restorative model of school discipline 
In sum, the observation and analysis of the detrimental effects of punitive school discipline in Nova Scotia have resulted in several recommendations over the past three decades (Barjun Consultants, 2001; Beagan \& Etowa, 2009; BLAC Implementation Review Committee, 2003; Black Learners Advisory Committee, 1994; James et al., 2010; Lee \& Marshall, 2009; Nunn, 2016). Yet tangible efforts are still warranted to implement and utilize alternative non-punitive disciplinary measures and curtail school discipline racial disproportionality.

\section{Nova Scotia school discipline guidelines}

To discuss alternatives to current school discipline practices, it is relevant to first review the classification of school misconduct as defined by the Department of Education and Early Childhood Development. Nova Scotia recently dissolved its school boards in favour of one provincial advisory committee (Laroche, 2018). Therefore, the school conduct policies reviewed in this section are solely from the province and the Department of Education and Early Childhood Development. Discipline involves the consequence that is applicable following the occurrence of a misconduct, which is referred to as an "unacceptable behaviour" in official government policy (House of Assembly Halifax 2018; Province of Nova Scotia 2015a, 2015b). Unacceptable behaviours are defined as anything that endangers the well-being of others, damages property, or "significantly disrupts the learning of others" (House of Assembly Halifax, 2018, p.7). The Education Act (2018) provides a list of unacceptable behaviours, such as bullying, physical violence, verbal abuse, and racist behaviour; however, these terms are subject to interpretation, and the enforcement of the policy relies on school personnel discretionary judgment. The purview of school personnel to identify the nature, bounds, and gravity of misconduct, and to sanction such behaviour, is not restricted to school grounds. Consequences can apply if misconduct takes place "at a location, activity, function or program that is off school grounds and is not school-sponsored or school-related, if the behaviour significantly disrupts the learning climate of the school" (House of Assembly Halifax, 2018, p.15). Broadly, the Provincial School Code of Conduct Policy (2015) explicitly specifies that all school community members are responsible for fostering awareness and the prevention of misconduct. The provincial code also underscores the expectation that schools will play a proactive and preventative role to reduce the occurrence of unacceptable behaviours. Several school community members have the ability to establish the nature and the consequence of a misconduct, and the Education Act (2018) defines their specific responsibilities (see Table 1).

Table 1

School professionals' responsibility regarding discipline

\begin{tabular}{|c|ll|}
\hline Role & \multicolumn{1}{c|}{ Responsibility } \\
\hline School support staff & $>$ are required to report unacceptable behaviour. \\
\hline Teachers & $>\begin{array}{l}\text { must engage in behavioural management to maintain order and } \\
\text { discipline in the classroom and on school grounds. } \\
\text { are required to report misconduct to the principal. }\end{array}$ \\
\hline $\begin{array}{c}\text { Principals and } \\
\text { vice-principals }\end{array}$ & $>$ have the duty to investigate and respond to reports of misconduct. \\
\hline
\end{tabular}

Source: From the Nova Scotia Education Act, (House of Assembly Halifax, 2018)

Toward an alternative community-driven restorative model of school discipline 
It is important to note that principals, vice-principals, teachers, and school support staff deploy their discretionary judgment when they apply the policy's guiding principles described in the Provincial School Code of Conduct Policy. These principles outline that the decision must take into account the safety and security of the school community, the duration, frequency and seriousness of the behaviour, the development of acceptable behaviours, the age and developmental stage of the student, the possible use of restorative practices, and the utilization of fair and consistent consequences that do not disproportionately impact students based on their identity (race, ethnicity, religion, sexual orientation, gender, gender identity or expression, disability, mental illness, age, national or aboriginal origin, socioeconomic status). While restorative practices are mentioned as a potential response, there is no clear instruction regarding what constitutes a restorative intervention, when it should be used, with who, and how.

\section{Figure 1}

Provincial guiding principles to respond to an unacceptable behaviour

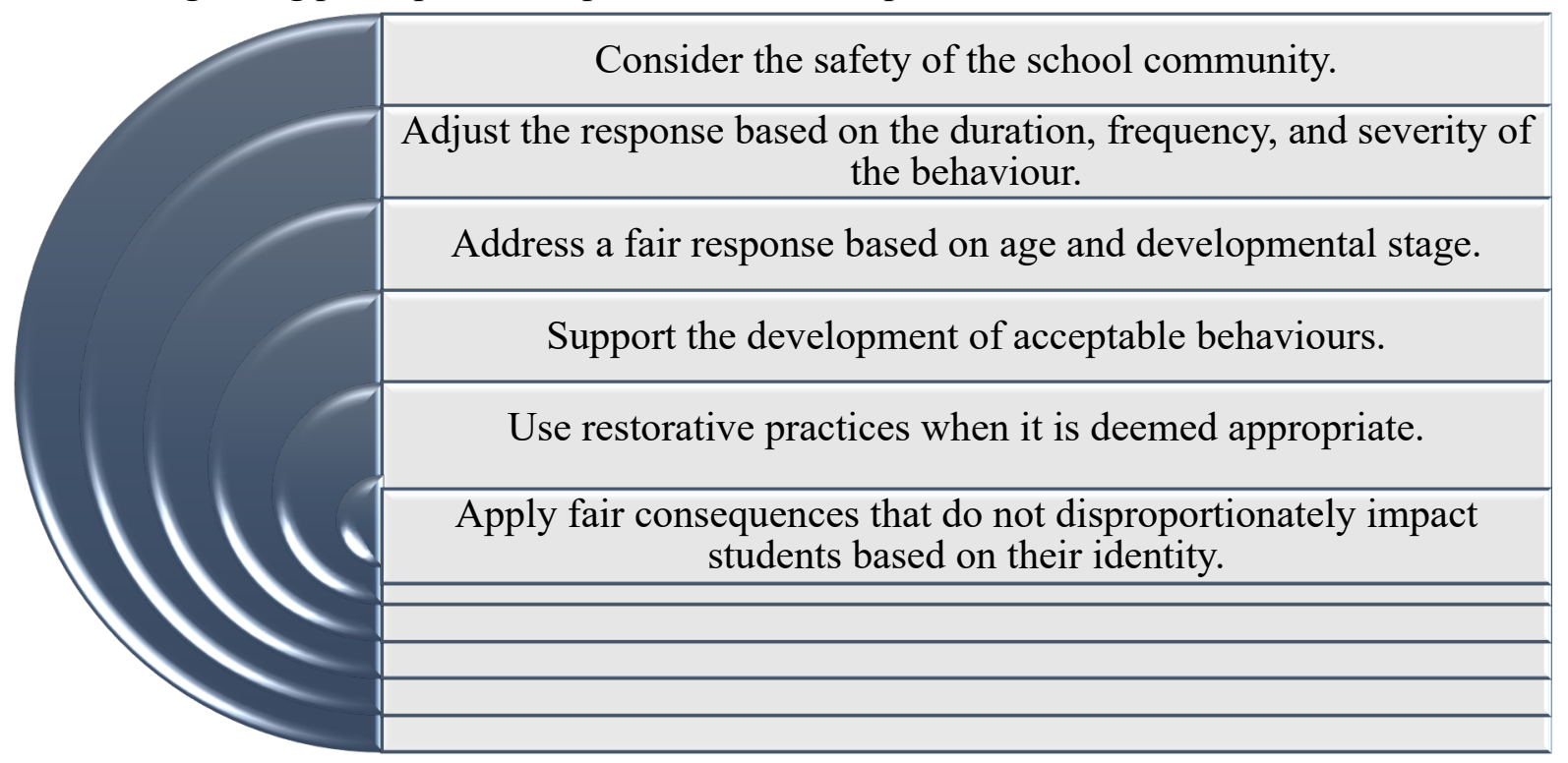

Source: From Nova Scotia Provincial School Code of Conduct (Province of Nova Scotia, 2015a)

Several responses are possible following an incident of misconduct, including but not limited to leaving the classroom, loss of privileges, referral to an advisor, guidance counsellor, or student support worker, creating a plan for restitution, mediation, parent conferences, detention, in-school suspension, out-of-school suspension, or a recommendation for an extended suspension period for more than 10 days (special permission required from a regional centre) (Province of Nova Scotia, 2015a, p.9). The Education Act further expands on the process of suspensions, stating that once one is issued, the student or parent can appeal and ask for a review by the regional centre (House of Assembly Halifax, 2018). The regional centre can confirm the suspension, or have it revoked and removed from the student's record. If a suspension for more than 10 days has been approved by a regional centre, then "the regional centre, in consultation with the student's parents, shall make every reasonable effort to provide alternative arrangements for the education of the student" (House of Assembly Halifax, 2018, p.17). While a case-by-case process is indicated to oversee school discipline incidents, it is important to note that this policy uses broad terms and relies on school personnel's discretionary judgment and circumstantial interpretation. Moreover, the policy does not sufficiently emphasize equity and the predominance of alternative non-punitive approaches of school discipline.

Toward an alternative community-driven restorative model of school discipline 


\section{Alternative school discipline interventions and models in the literature}

In North America, the predominant approach to school discipline is grounded in correction and deterrence purposes, with measures such as suspension and expulsion (Skiba \& Peterson, 2000; Winton, 2013). Along with a punitive approach, some school administrators have opted for the use of fences, locks, cameras, and security or police officers with the security and safety goals. However, several scholars suggest that "zero tolerance" policies and "tough on delinquency" approaches can worsen or escalate anti-social behaviours, especially among students who have multiple and complex needs (Gregory et al., 2010; Mayer, 2001). Punitive discipline also disproportionately impacts racialized students, and in the case of Nova Scotia, Black learners (Hayle et al., 2016; Salole \& Abdulle, 2015; Shirley \& Cornell 2012; Woodbury, 2016). Others have also highlighted that an early encounter with law enforcement in school increases the likelihood of future incarceration, which is often referred to as the "school to prison pipeline" (Bernard \& Smith, 2018; Noguera, 2003; Salole \& Abdulle, 2015).

There is an established scholarly literature that documents the advantages and transformative potential of alternative non-punitive discipline interventions and models. Alternative discipline interventions are often introduced by school administrators and teachers to address student misconduct in a way that also builds the individual student's character while improving the overall school community climate. These interventions often encourage prosocial behaviours, provide frequent positive reinforcement, and value a relational approach, while also recognizing the possibility that some students with behavioural problems may require an individualized intervention plan. In fact, there are common principles shared by alternative nonpunitive school discipline interventions and models.

Figure 2

Common principles of alternative non-punitive disciplinary interventions and models
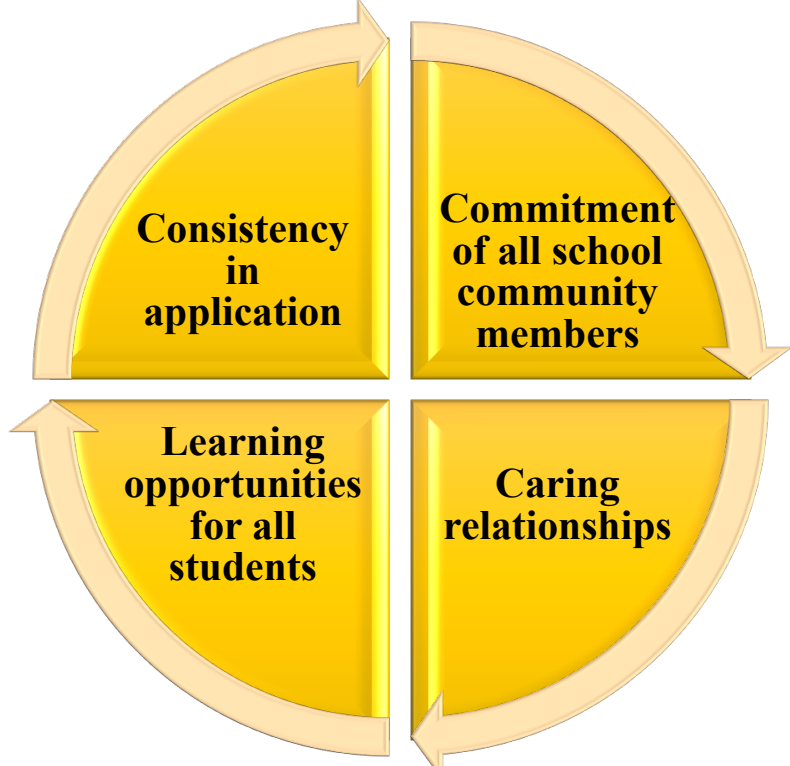

Source: Alternative school discipline principles and interventions: an overview of the literature (Jean-Pierre \& Parris-Drummond, 2018)

Toward an alternative community-driven restorative model of school discipline 
In principle, alternative school discipline interventions build upon caring relationships between school personnel and students; necessitate the commitment and engagement of all the administrators, teachers, staff, and students; provide all students with learning opportunities (e.g. accommodation or culturally relevant education); and consistently apply clearly pre-established conduct expectations and consequences (Jean-Pierre \& Parris-Drummond, 2018). Alternative school discipline practices fall into two categories: individualized interventions which target students with chronic, frequent, or violent behavioural problems, and school-wide models which aim to uplift the overall school climate. Several administrators select a school-wide model, combined with a number of individualized interventions, to address misconduct.

\section{Figure 3}

Two categories of alternative non-punitive practices of school discipline

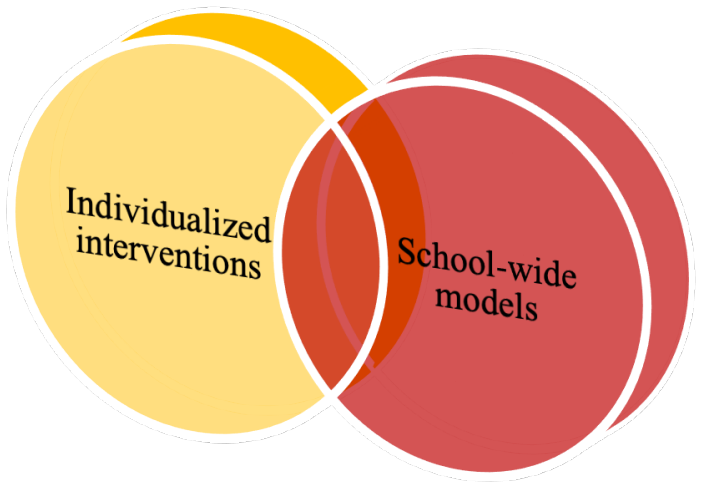

Source: Alternative school discipline principles and interventions: an overview of the literature (Jean-Pierre \& Parris-Drummond, 2018)

Individualized interventions seek to address the needs of students with chronic or frequent behavioural problems who have often been identified by teachers and other school staff (Hawken et al., 2007). The behavioural or the check-in/check-out program entails the pairing of a student with a staff for brief daily meetings (five minutes or less) at the beginning (check-in) and at the end (check-out) of the school day (Goodman-Scott, 2013). At the beginning of the day, the behavioural goals are established, and at the end of the day, the student and school personnel review and discuss them (Swoszowski et al., 2013). The school survival group is an after-school program in which a maximum of 10 students discusses their motivation and cognitive processes, and participate with the use of games and life scripts in 50 minutes (Dupper, 1998; Ryan \& Zoldy, 2011). During these sessions, the students unpack the emotional triggers, decision-making processes, and possible alternative behaviours in order to develop a greater focus of control. Conflict resolution and social-cognitive skills training focuses on the development of competencies that enable positive behavioural responses to challenging situations instead of polarization, violence, or impulsive, negative behaviours (Breunlin et al., 2002; Ryan \& Zoldy, 2011). A clear assumption of the training is that students can learn to engage in dialogue, negotiation, active listening, and self-control (Greene, 2011). Comprehensive school counseling is another strategy mobilized to foster self-regulation, and it involves a deep exploration of socialemotional and cognitive processes and positive reinforcement (Lapan, 2012). Time out rooms, group therapy, or individual counselling sessions are also delivery formats of counseling in schools (Nielsen, 1979). Another individual intervention is detention, which takes place after-school or during lunchtime (Andrews et al., 1998), while in-school suspension often lasts all day (Sanders, 2001). In-school suspension provides students a safe location supervised by adults where they can

Toward an alternative community-driven restorative model of school discipline 
continue to access formal education (Sanders, 2001). School administrators can easily combine inschool suspension with counseling sessions, conflict resolution and social-cognitive skills training, or the survival group.

\section{Figure 4}

Alternative individualized interventions of school discipline

\section{Behavioural education plan}

\section{School survival group}

\section{Conflict resolution and skills training}

\section{School counseling}

\section{Detention and in-school suspension}

Source: Alternative school discipline principles and interventions: an overview of the literature (Jean-Pierre \& Parris-Drummond, 2018)

Among alternative school-wide models, we find: a) the authoritative model; b) the democratic or student-driven model; c) restorative practices in education; d) strength-based or the empowerment model; and e) the positive discipline model. School-wide models can be transformative, and can improve the sense of safety and belonging of school community members while strengthening the academic achievement of all students, with less disruption in the classroom.

The authoritative school discipline model draws its core components from the authoritative parenting style model, which values the combination of structure and support (Baumrind, 1966, 1996). Structure consists of the consistent and fair enforcement of school rules, while support consists of the care and attention provided by school personnel to each student (Gerlinger \& Wo, 2016). This model stresses the development of positive and caring relationships with students, while upholding high expectations and school norms (Gregory \& Cornell, 2009). The authoritative model of school discipline is often considered a good foundation that should be combined with another school discipline model, because it is primarily preventative and does not provide clear guidelines to respond to misconduct.

Democratic and student-driven models of school discipline delegate the power to conceive, implement, and enforce school discipline to students. Students acquire leadership, civic, and communication skills as they write a school constitution (Grandmont, 2003) or volunteer to sit on a student-led disciplinary committee (Hantzopoulos, 2011). The literature points to some limitations of this model, including parents' disapproval and the challenge of convincing teachers to relinquish their power (Cuevas \& Kralovec, 2011). 
Restorative practices in education are based on restorative justice, an approach applied in some circumstances in the criminal justice system and inspired by New Zealand Maori customs and Canadian Indigenous healing circles (Ryan \& Ruddy, 2015). In education, restorative practices focus on the importance of fostering social relationships, engagement in school community, respect for others, and on "the need to restore good relationships when there has been conflict or harm" (McCluskey et al., 2008, p. 405). Restorative practices can therefore be preventativeeducating students on the value of empathy and conflict resolution - and responsive when an incident occurs. When a student has not followed school rules, the focus is not on the misconduct itself, but on the resolution and repair of relationships (Anfara et al., 2013; Martin, 2015). The core principles of restorative practices include the belief that behaviour is a form of communication, an assumption that misconduct is the expression of an unmet need, the recognition of individual responsibility for the harm caused, the intent to repair the harm and restore relationships to empower the community, and the goal of addressing power imbalances by considering the possible harm experienced by students in institutions (Anfara et al., 2013; Martin, 2015; Zehr, 2002).

A strength-based approach of discipline acknowledges and builds on the abilities of students, and seeks to empower marginalized students. In an Oakland school, this model was implemented with a committee to address the high suspension and expulsion rates of Black and Latino students (Day-Vines \& Terriquez, 2008). This committee, called "Youth Together", included advocates, parents, school staff, and students to proactively raise awareness about rules and consequences to all school community members, to monitor and track monthly principal's office referrals, to provide guidance and support to teachers with the highest rates of principal's office referrals, and to promote equitable practices (Day-Vines \& Terriquez, 2008). This model was successful, with a decline in suspensions of $75 \%$. Youth were empowered to use data and prepare compelling, empirically supported arguments regarding disciplinary practices (Day-Vines \& Terriquez, 2008). Another example of such a model is the all-Black, all-male manhood development class, wherein a Black male teacher used his charisma to incorporate what could be seen as disruptive behaviour into the class (Nasir et al., 2013). The students themselves created a class constitution and agreed on a set of rules, which fostered student development and the mutual respect of classmates (Nasir et al., 2013). Discipline occurred only when this constitution was violated, and students were observed to be willing to take responsibility (Day-Vines \&Terriquez, 2008). Strength-based and empowerment models of school discipline involve the creation of a code of conduct, and continuous collaboration with transparency, consistency, collaboration, mutual respect, and dialogue in a way that is meaningful to students.

The most well-known and assessed alternative discipline model is the positive discipline model, which has several names in the literature: positive behavioural supports (PBS), schoolwide positive behavioural supports (SWPBS), positive behavioural interventions and supports (PBIS), and school-wide positive behavioural interventions and supports (SWPBIS) (GoodmanScott, 2013). The fundamental goals of positive behavioural supports are to intentionally teach and reinforce positive behaviours, and to explore the students' motives for misconduct or breach of the code of conduct (Swoszowski et al., 2013). This model is widely adopted, and is recommended by the United States Department of Education as a preventative framework and as an effective and socially valid intervention for students with behavioural problems (Goodman-Scott, 2013; Swoszowski et al., 2013). Yet this model fails to support students with chronic or frequent behavioural issues, has not been found to be necessarily effective in high schools, and does not build a student's character, intrinsic motivations, and locus of control (MacAllister, 2014; Warren et al., 2006; Woods, 2008).

Toward an alternative community-driven restorative model of school discipline 
Figure 5

Alternative school-wide models of school discipline

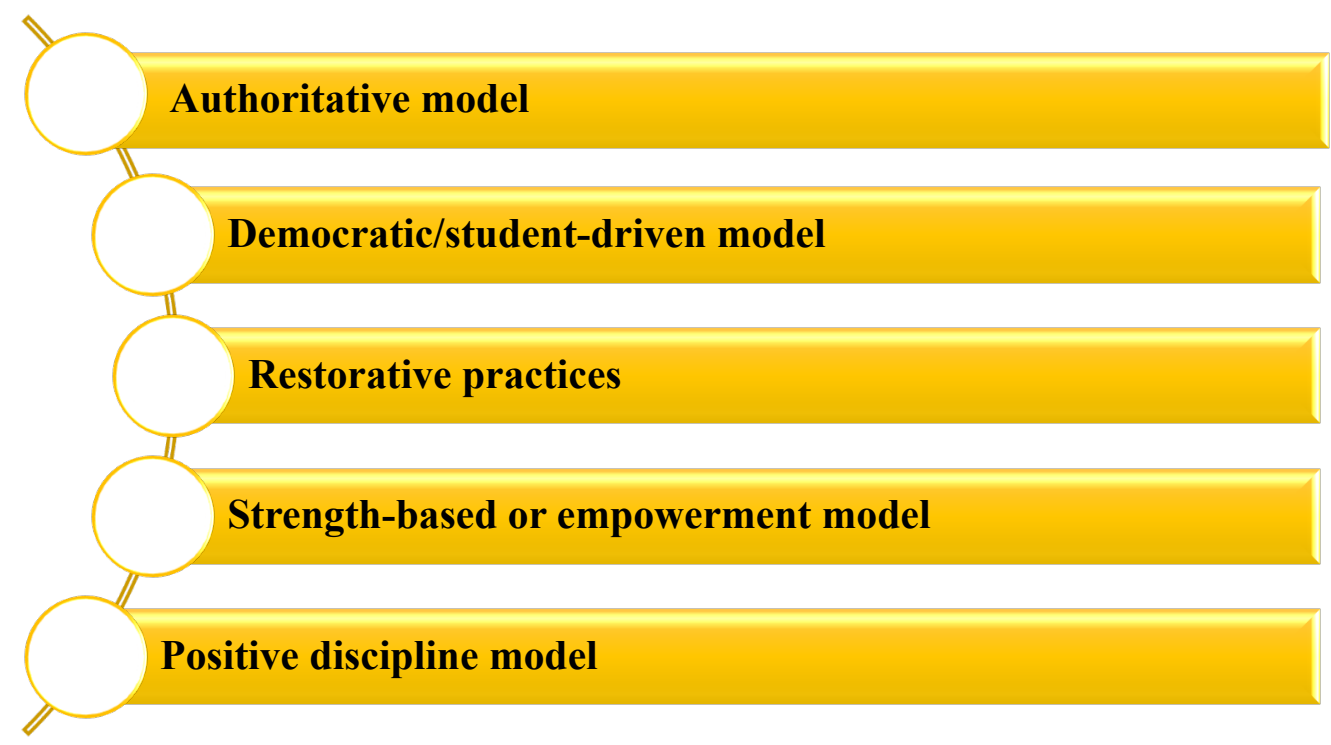

Source: Alternative school discipline principles and interventions: an overview of the literature (Jean-Pierre \& Parris-Drummond, 2018)

There are fundamental principles that favour the successful transition and sustainability of the implementation of an alternative non-punitive school model. Successful implementation is overseen by a committee that ensures the seamless transition from the status quo to an alternative non-punitive model, and then systematically collects discipline-related data (Jean-Pierre \& ParrisDrummond, 2018). Following a periodic review of the data collected (e.g. bi-weekly or monthly), committee members can identify students who may need additional support and peak times of misconduct, help adjust program implementation, and provide positive feedback to the school community (Jean-Pierre \& Parris-Drummond, 2018). There also must be clear communication and the understanding of rules and expectations by everyone - students, parents, teachers, support staff, and administrators. Alternative models of school discipline address misconduct while also maintaining students in the school environment and encouraging the development of students' social, cognitive, and emotional skills. Thus, moving away from a punitive approach shifts the focus towards positive reinforcement, relationship-building, students' character development, and more time dedicated to formal learning.

\section{Methodology}

Grounded in the assumption that it is essential to value the agency and knowledges of people of African descent in order to design sustaining and equitable solutions for contemporary challenges, this inquiry mobilized a qualitative research design through storytelling in order to centre marginalized voices and account for the role of racism in everyday life (Mazama, 2001; Solorzano \& Yosso, 2002). A qualitative design, which combined individual semi-structured interviews and focus groups, facilitated the inquiry into individual and collective perceptions, interpretations, and meaning-making processes of school discipline practices of participants (Bryman \& Bell, 2019). Ryerson University Research Ethics Board approved this research protocol.

Toward an alternative community-driven restorative model of school discipline 
This study took place in 2018 and 2019 and consisted of 17 semi-structured interviews and nine focus groups with three to seven participants, with a total sample of 60 participants (see table). Data collection took place in-person in Nova Scotia, by phone, and virtually via Zoom, in order to facilitate the recruitment of participants from various urban and rural regions throughout the province in both official language communities. On average, the interviews lasted 45 minutes, while the focus groups lasted one hour.

Table 2

Participants' age group and self-identified origin

\begin{tabular}{|c|r|r|r|}
\hline & Youth 12<24 & Adults $>\mathbf{2 4}$ & \multicolumn{2}{|c|}{ Total } \\
\hline African Nova Scotian & 10 & 29 & 39 \\
\hline Black immigrant & 5 & 15 & 20 \\
\hline Other* & 0 & 1 & 1 \\
\hline Total & 15 & 45 & 60 \\
\hline
\end{tabular}

*A professional who works closely with Black community members participated in the study.

Table 3

Participants' gender and language

\begin{tabular}{|c|c|c|c|}
\hline & Women & Men & Total \\
\hline French-speaking & 8 & 4 & 12 \\
\hline English-speaking & 26 & 22 & 48 \\
\hline Total & 34 & 26 & 60 \\
\hline
\end{tabular}

The interviews and focus groups were recorded, transcribed, and coded using the qualitative software MAXQDA (VERBI, Berlin, Germany). We then engaged in a thematic analysis of participants' narratives to analyse the salient topics discussed, create categories and sub-categories, and determine the main themes. In this report, we discuss two themes that were prevalent among participants from various regions in English and in French. In order to maintain participants' confidentiality, any identifiable characteristic has been removed from the narratives, and pseudonyms are used.

\section{Results}

Participants responded to questions about their appreciation of current discipline practices, what an Africentric or community-based school discipline model would look like, and what teachers, vice-principals, principals, and the Department of Education should do to improve disciplinary interventions. The topic of school discipline evoked responses from all the participants that comprised lived experiences, sentiments, and alternative practices that can help eliminate school discipline racial disproportionality and support Black students' development. Regarding the conception of alternative non-punitive interventions, the participants provided insights that can be categorized in two major themes (see figure 6):

Toward an alternative community-driven restorative model of school discipline 
1) Alternative non-punitive interventions are needed, particularly a restorative approach; and

2) These practices must be embedded within an overhaul of curricular and pedagogical practices, which involves an organizational cultural shift.

Figure 6

Major themes of the findings of the study

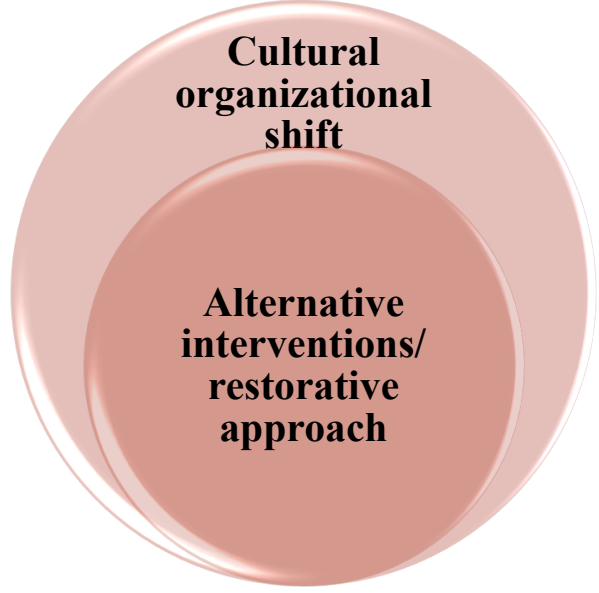

\section{Preconditions and sustainable implementation of alternative non-punitive interventions}

According to several community members, we can curtail the use of punitive school discipline interventions, such as detentions, suspensions, and expulsions, by intentionally planning the sustainable implementation of alternative non-punitive interventions. To do so, some preconditions are essential, including a) fostering a caring and nurturing learning environment; $b$ ) adopting curricular and pedagogical practices that enable all students to learn; c) applying consistently transparent and fair behavioural norms and consequences; and d) embracing a restorative model of school discipline (see Figure 7).

Figure 7

Essential preconditions

\section{Embracing a restorative model of school discipline}

\section{Applying consistently transparent and fair} behavioural norms and consequences

Adopting curricular and pedagogical practices that enable all students to learn

Fostering a caring and nurturing learning environment for all students 
a) Fostering a caring and nurturing learning environment for all students

It is important that all students feel cared for, appreciated, and nurtured in the school system. Participants reported that Black students should be given as much attention, opportunity, and positive reinforcement as other students in the classroom. The literature does support that when adults develop caring relationships with students, it is beneficial for learning, and encourages positive behaviours (Dei, 1996; Gregory \& Cornell, 2009; Olley et al., 2010). When students like Dionysia feel overlooked in comparison to her classmates, it indicates that this precondition needs to be reinforced among teachers.

"Dionysia, a high school student, shared that this perceived lack of interest also translated into opportunities in the classroom that differed along racial lines: 'I feel like they give the White kids more opportunities, and they'll be like, show more affection toward them, if that makes sense" (Jean-Pierre, 2021, p. 10)

b) Adopting curricular and pedagogical practices that enable all students to learn

According to participants, school administrators and teachers should recognize and act proactively to remove barriers to learning in the classroom in a comprehensive way. This can involve, for example, acknowledging that hunger can prevent a student from learning, and that providing a meal or a snack might result in less disruptive behaviour. Other barriers to learning should also be removed, and scholars have indicated that, in order to address misconduct, it is paramount that schools address students' academic and other complex needs (Gregory \& Cornell, 2009; Simmons, 2009). In fact, scholars have proposed that the achievement gap and school discipline disproportionality are interrelated, and should be addressed simultaneously by focusing on a range of needs, such as mental health, learning disabilities, poverty, literacy, and a lack of a culturally relevant curriculum (Beckford, 2016; Fowler, 2011; Gregory et al., 2010; Jean-Pierre, 2021; Noguera, 2003; Skiba \& Losen, 2015). Edith's comment below reflects the importance of responding to immediate needs.

"If hunger is the reason the child is acting out, how can we make that a priority every day? If it's a lack of connection, if it's homelessness, like we need to look at a more encompassing model." Edith

c) Applying consistently transparent, consistent, and fair behavioural expectations, norms, and consequences

Several participants reported that they believe that Black learners are disciplined more severely than their peers, even when they engaged in the same misconduct as other students. This finding confirms previous studies' findings (James et al., 2010; Ruck \& Wortley, 2002; Salole \& Abdulle, 2015). There are also concerns that Black learners are often not provided with the opportunity to give their own account of an incident, and that they are often assumed to be at fault before they are questioned. In order to promote a sense of belonging in school, and to avoid the development of feelings of alienation, it is essential to create mechanisms that provide transparent, consistent, and fair treatment of misconduct. This can be accomplished by delineating in writing, and early in the school year, all the prohibited behaviours and the consequences associated with each type of misconduct. It is subsequently important to inform teachers, staff, parents, and students about the behavioural expectations and pre-determined consequences. As indicated in the provincial policy Toward an alternative community-driven restorative model of school discipline 
for misconduct, there is latitude provided to enact one's discretionary judgment to assign consequences. However, the way discretionary judgment is applied seems to disadvantage Black students. This trend is certainly connected to the negative and culturally mediated stereotypes that Black students are violent and less deserving of second chances (James, 2012). These stereotypes can have significant and detrimental effects on shaping professionals' worldview in other domains, as even in the criminal justice system, Black young offenders are considered less frequently for diversion and extrajudicial programs (Samuels-Wortley, 2019; Williams, 2013). An observation from Inez reflects the preoccupation regarding racial bias and unfair treatment.

"For someone else it might just be like, okay, go outside and cool down, for this student it's like, go to the office, and then they're sent home." Inez

d) Embracing restorative practices in education to address misconduct in the school system

Several participants believed that restorative practices would be more appropriate and better aligned with African Nova Scotians' culture and traditions when addressing misconduct. This process could include students, teachers, parents, and elders. While the Nova Scotia Provincial School Code of Conduct Policy mentions restorative practices, they are not fully detailed and explained. Restorative practices in education are relational, and can promote children and youth's character development and sense of belonging, as well as a better school climate (Anfara et al., 2013; Martin, 2015; McCluskey et al., 2008). Like other alternative models of school discipline, it is essential for the successful implementation of this model that the whole school community adheres to and engages with it (Day-Vines \& Terriquez, 2008). Imelda expresses this preference for restorative practices in order to repair the relationship and address the harm.

"So restorative circles or restorative processes, I think, work really best for children. So instead of looking at expulsions, or instead of looking at punishment, let's look at repair." Imelda

\section{A cultural organizational shift: the overhaul of curricular and pedagogical practices}

There is large consensus among participants that without a major cultural organizational shift, alternative practices of school discipline alone would not fully address school discipline racial disproportionality. Participants expressed that an overhaul of curricular and pedagogical practices is needed to achieve inclusive education.

School administrators can focus on addressing anti-Black racism, adopting a culturally relevant and sustaining curriculum and pedagogy, and increasing the number of Black teachers and staff in schools. These participants' suggestions reiterate recommendations from previous reports and published articles, as well (Barjun Consultants, 2001; BLAC Implementation Review Committee, 2003; Black Learners Advisory Committee, 1994; Brathwaite, 2010; Dei, 1996; Hamilton-Hinch et al., 2017; Jean-Pierre, 2021; Lee \& Marshall, 2009). Once more, participants highlighted the importance of taking seriously anti-Black racism incidents, providing anti-racist training to teachers and staff, integrating Black history, culture, and knowledges in the curriculum, and increasing the presence of Black role models in schools with Black teachers and African Nova Scotian student support workers.

Toward an alternative community-driven restorative model of school discipline 


\section{Figure 8}

Participants' views about school personnel's role for a cultural organizational shift

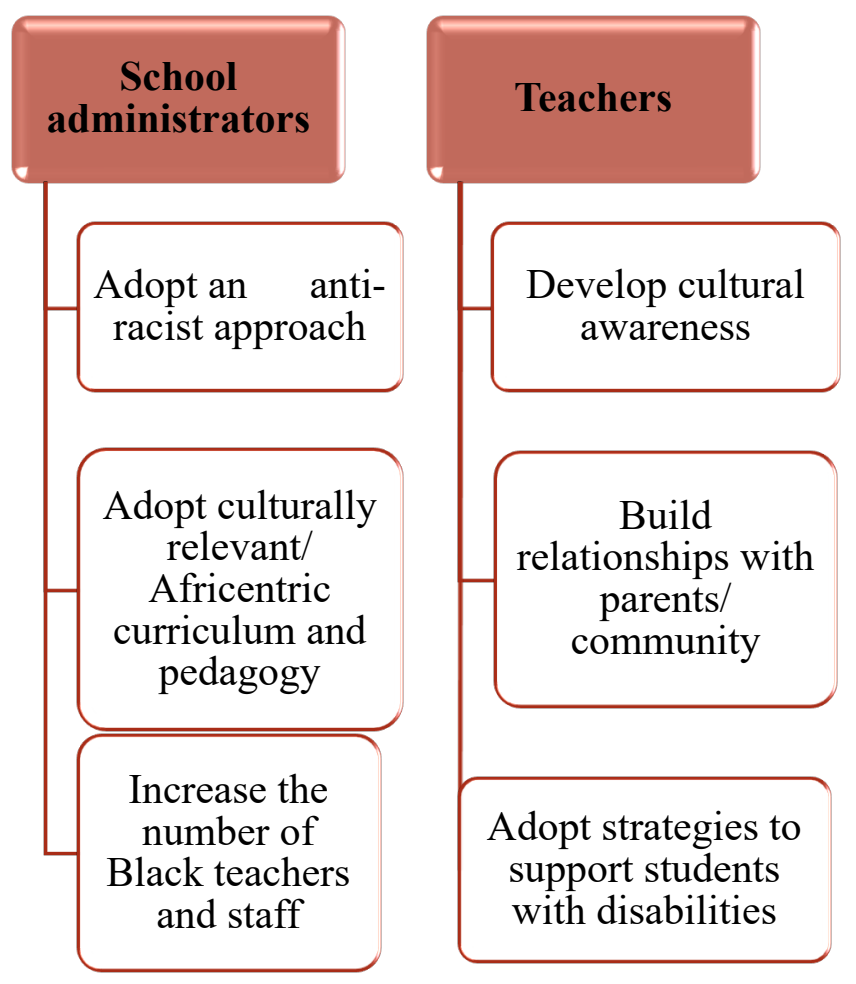

Simultaneously, teachers and staff can develop greater cultural awareness about students' lived experiences, and build better relationships with parents and the community while adopting effective teaching strategies to support students with disabilities. With the exception of the latter, these participants' insights reiterate previous research findings (Codjoe, 2007; Hamilton-Hinch et al., 2021; Livingstone et al., 2014; Malinen \& Roberts-Jeffers, 2019). Several participants stated that teachers and staff do not understand the context and history of Black learners and could develop deeper and broader cultural awareness. Participants also consider that by communicating with parents regularly, and participating in community activities, teachers can expand their cultural awareness regarding Black students. It was also noted that teachers learn to teach effectively to all students, including students with disabilities, by using alternative pedagogical strategies. Greater attention should also be paid when race and disability intersect-in other words, when Black learners are suspected of having or have been identified as having a disability.

Although there have been efforts to support the education of Black learners in Nova Scotia, some institutional barriers remain, and additional initiatives are needed to achieve an inclusive classroom environment. The findings of this report and the literature point to a pathway towards different outcomes. For instance, in schools, a committee that monitors and addresses disciplinary interventions on a regular basis can make a difference. This committee can identify students with frequent behavioural issues to address their needs early, and can also observe misconduct peak times and implement prevention strategies for the future. The same committee can also identify and support teachers with the highest number of principal's referrals, and uphold transparent, fair, and consistent responses to misconduct. A strategy to move forward that should involve the Toward an alternative community-driven restorative model of school discipline 
leadership and input of Black community members is a pilot project in different schools to investigate and document which restorative practices are most beneficial to students with a range of needs and behavioural challenges. Moreover, the creation of a well-resourced, community-led, and culturally relevant space - one grounded in an Africentric paradigm-for suspended and expelled Black students, should also be considered, so that these students can be helped to pursue their education during a time in which their complex needs are being addressed. The use of this space should be limited to exceptional cases, and would have to be carefully planned, because it is primarily the responsibility of schools to provide the adequate resources for Black learners.

\section{Conclusion}

Given the current and increasing diversity of the student population in Nova Scotia, and the importance of education for individual and societal aspirations, it seems imperative to relentlessly seek innovative and effective ways of enhancing the learning experiences of all students through the creation of inclusive learning environments. School discipline disproportionality, as well as unfair and inconsistent disciplinary practices, alienate Black children and youth from school, impede relationship-building with Black parents and communities, and have detrimental effects on the educational and life trajectories of Black learners. This report's research findings build upon the existing scholarly literature and previous reports, and point towards needed institutional changes to foster Black learners' academic success. An important finding in this report is that implementing alternative school discipline practices alone would be insufficient. Participants insist that several other compounding factors affect or amplify behavioural challenges, and that an overhaul of the school environment is required.

To provide a school environment conducive to learning for all students, including Black learners, school administrators can play a critical role in intentionally promoting teachers' professional development, increasing the number of Black teachers, student support workers, and other school professionals, and building relationships with Black parents and communities. Teachers can also make a real difference by intentionally developing caring relationships with Black students, fostering relationship-building with Black parents and communities, engaging in anti-racism and culturally relevant pedagogy training regarding restorative practices in education, and adopting various pedagogical practices for students with different learning styles.

To specifically address school discipline racial disproportionality, participants have reported that adults in the school should foster a caring and nurturing environment, and build positive relationships with Black students. There is also a need to address the various complex needs of students that impede learning. It is imperative that school administrators oversee the implementation and monitoring of transparent, consistent, and fair school conduct expectations and consequences. This can be better achieved with a committee that can monitor principal's referrals and identify students and teachers who need support. Ultimately, a restorative model of school discipline, co-designed with Black Nova Scotian community members, could improve the school climate for all students.

In light of the findings of this study, it is recommended that the Department of Education and Early Childhood Development and Black community organizations work collaboratively toward a strategic plan. This plan could include a community-driven alternative restorative model of school discipline, professional development opportunities for school professionals to learn the Africentric paradigm, anti-racism, culturally relevant pedagogy, and restorative practices, the Toward an alternative community-driven restorative model of school discipline 
hiring of Black teachers and professionals, and data collection of school discipline statistics at the provincial level to monitor progress over the years. We contend that a collaborative approach with the Black community can provide the input for the conception, operationalization, implementation, evaluation, and adjustments necessary for a sustainable model of school discipline that will promote Black learners' development, well-being, and academic success.

One possibility that a joint committee should consider is the implementation and evaluation of a pilot project with two components: a) a school in which a restorative model would be implemented and monitored over three years (minimum); and b) the potential of a well-resourced (including professionals, physical space, equipment, etc.) alternative learning space in which suspended and expelled students could continue their learning with a culturally relevant and sustaining approach. Community members could co-design and co-monitor, at every stage, within a collaborative and reciprocal relationship with the Department of Education and Early Childhood Development in Nova Scotia, the implementation and application of an alternative model that curtails school discipline racial disproportionality, and fosters inclusive education for all students. 


\section{Overall recommendations derived from the research project}

1. We reiterate previous reports' recommendations that alternative disciplinary practices in schools should be implemented to achieve inclusive education for all students.

2. To ensure the adoption of culturally relevant interventions, we endorse the BLAC report's recommendation that any new policy or practice necessitates Black students', parents', and advocates' input (Black Learners Advisory Committee, 1994). For instance, community elders could play a role in supporting restorative practices in schools.

3. Alternative disciplinary procedures must include preventative measures that promote a caring and nurturing school environment in which all students feel that they belong.

4. Teachers should intentionally reflect upon how they can establish caring and positive relationships with Black learners through various strategies and frequent interactions.

5. Given the fact that Black students are overrepresented among suspended students, we further suggest that an alternative restorative model of school discipline should be codesigned, co-implemented, and co-monitored with Black advocates and community organizations.

6. A community-driven restorative model of school discipline, co-monitored and co-led by Black Nova Scotians, should be piloted in a number of schools to assess its benefits among students with various needs.

7. It is paramount to expand access to professional development and training opportunities for teachers regarding restorative practices in education during pedagogical days.

8. We recommend the creation of a Black community-led learning space to support Black learners who have been suspended or expelled. This space should be well resourced to provide culturally relevant services that can address complex and multiple needs. This space needs to be carefully planned so that it is used only exceptionally, and does not result in feelings of alienation from school. The purpose of this space would be to ensure that, during a transitional or short period of time, suspended or expelled students continue to learn.

9. Given the degree of discretionary judgment accorded to school personnel, in every school, an alternative model of school discipline should include the creation of a committee that

Toward an alternative community-driven restorative model of school discipline 
monitors the nature of and responses to disciplinary incidents on a bi-weekly or monthly basis. This committee will be able to support teachers and students frequently involved in incidents that result in principal's office referrals.

10. Following a consultation with the wider community and various stakeholders, we contend that it would be beneficial to revise the Provincial School Code of Conduct Policy to better circumscribe misconduct and responses to misconduct, and to emphasize alternative disciplinary actions, including restorative practices in education.

11. In order to ensure consistent and fair disciplinary interventions, at the beginning of each school year, school personnel should provide a detailed code of conduct with explicitly named, prohibited behaviours, along with the pre-determined consequences to students and parents.

12. In each school, in order to treat each student fairly, principals, vice-principals, and teachers should listen to Black learners' stories and perspectives when they are involved in misconduct, and not solely rely on previous impressions or other students' accounts.

13. School administrators should create an environment conducive to learning for all students, which may require working with other human services agencies and community organizations to address complex needs, such as poverty or social-emotional needs.

14. Anti-racism and an Africentric paradigm should be better reflected in curricular and pedagogical practices.

15. There is a need to build relationships with Black parents and communities to develop greater cultural awareness and understanding of Black learners' lived experiences.

16. More Black teachers, student support workers, and other professionals should be hired. 


\section{Recommendations from attendees during a community forum (Halifax, Thursday March $12^{\text {th }}$ 2020)}

On March $12^{\text {th }}$, a community forum was held at the Westin Nova Scotian Hotel to present the preliminary findings of this study. Here is a summary of attendees' written recommendations.

17. There is a need for more Black teachers and African Nova Scotian student support workers, and there should be more professional development opportunities and support for individual Black teachers and personnel.

18. The Ministry of Education should initiate the evaluation of bachelor's degrees of education (B.E.D.) and other teaching certification processes across the province to assess the curricular and pedagogical approaches mobilized to prepare teacher candidates to work with Black learners. This evaluation should examine how teachers are taught about culturally relevant and sustaining pedagogies, an Africentric paradigm, anti-racism, and Black learners' contexts.

19. Various forms of training should be offered to administrators, teachers, and staff during pedagogical days, as well as prospective teacher candidates, and should incorporate the following topics:

a) anti-Black racism and anti-racist strategies in education;

b) culturally relevant and sustaining curriculum and pedagogy;

c) the Africentric paradigm's principles, along with examples of existing Africentric community-based initiatives;

d) a trauma-informed approach to education;

e) workshops and certification in restorative practices in education.

20. The school community should develop a holistic approach to better communicate and engage with Black parents and Black community organizations. On the one hand, school administrators and teachers should involve community organizations in school activities and projects. On the other hand, administrators and teachers need to be more present in communities to be "in the know". It was suggested that administrators and teachers could partake in an African Nova Scotian community immersion program, such as a summer immersion program, in which they could come to see the community in action for a period of time. 


\section{References}

African Nova Scotian Affairs. (2020, July 19). African Nova Scotian Community. https://ansa.novascotia.ca/community

Andrews, S. P., Taylor, P. B., Martin, E. P., \& Slate, J. R. (1998). Evaluation of an alternative discipline program. The High School Journal, 81(4), 209-217.

Anfara, V.A., Evans, K. R., \& Lester, J. N. (2013). Restorative justice in education: What we know so far. Middle School Journal, 44(5), 57-63. https://doi.org/10.1080/00940771.2013.11461873

Barjun Consultants. (2001). Final Report of The African Nova Scotian Education Summit. Council on African Canadian Education.

Baumrind, D. (1966). Effects of authoritative parental control on child behavior. Child Development, 37(4), 887-907. https://doi.org/10.2307/1126611

Baumrind, D. (1996). The discipline controversy revisited. Family Relations, 45(4), 405-414. https://doi.org/10.2307/585170

Beagan, B. L., \& Etowa, J. (2009). The impact of everyday racism on the occupations of African Canadian women. Canadian Journal of Occupational Therapy, 76(4), 285-293. https://doi.org/10.1177/000841740907600407

Beagan, L.B., Etowa, J., \& Bernard, W.T. (2012). "With God in our lives he gives us the strength to carry on": African Nova Scotian women, spirituality, and racism-related stress. Mental Health, Religion \& Culture, 15(2), 103-120. https://doi.org/10.1080/13674676.2011.560145

Beckford, C. (2016). Connecting the dots through a case report: A child's unmet needs, neuropsychological impairment and entrance into the juvenile justice system. Journal of Infant, Child, and Adolescent Psychotherapy, 15(3), 188-209. https://doi.org/10.1080/15289168.2016.1214447

Bernard, W.T., \& Smith, H. (2018). Injustice, justice, and Africentric practice in Canada. Canadian Social Work Review/Revue canadienne de service social, 35(1), 147-155. https://doi.org/10.7202/1051108ar

BLAC Implementation Review Committee. (2003). Report of the BLAC Implementation Review Committee. Nova Scotia Department of Education.

Black Learners Advisory Committee. (1994). Black Report on Education Vol 1-3. Black Learners Advisory Committee.

Brathwaite, O. (2010). The role of the school curriculum to obliterate anti-Black racism. Our Schools/Our Selves, 19(3), 305-326.

Breunlin, D. C., Bryant-Edwards, T. L., \& Hetherington, J. S. (2002). Conflict resolution training as an alternative to suspension for violent behavior. The Journal of Educational Research, 95(6), 349-357. https://doi.org/10.1080/00220670209596609

Toward an alternative community-driven restorative model of school discipline 
Bryman, A., \& Bell, E. (2019). Social Research Methods, $5^{\text {th }}$ Canadian Edition. Oxford University Press.

Bundy, J. (2019). 'We'll deal with it later': African Nova Scotian women's perceptions and experiences of the police. Canadian Journal of Sociology/Cahiers canadiens de sociologie, 44(4), 319-341. https://doi.org/10.29173/cjs29473

Clairmont, D. H., \& Magill, D.W. (1970). Nova Scotia Blacks: An Historical and Structural Overview. Institute of Public Affairs.

Codjoe, H. M. (2007). The importance of home environment and parental encouragement in the academic achievement of African Canadian youth. Canadian Journal of Education/Revue canadienne de l'éducation, 30(1), 137-156. https://doi.org/10.2307/20466629

Cuevas, G., \& Kralovec, E. (2011). Trusting students to lead: Promise and pitfalls. Schools: Studies in Education, 8(1), 143-165. https://doi.org/10.1086/659444

Day-Vines, N. L., \& Terriquez, V. (2008). A strength-based approach to promoting prosocial behavior among African American and Latino students. Professional School of Counseling, 12(2), 170-175. https://doi.org/10.1177/2156759X0801200204

Dei, G.J.S. (1996). The role of Afrocentricity in the inclusive curriculum in Canadian schools. Canadian Journal of Education, 21(2), 170-186.

Dupper, D. R. (1998). An alternative to suspension for middle school youths with behavior problems: Findings from a "school-survival" group. Research on Social Work Practice, 8(3), 354366. https://doi.org/10.1177/104973159800800307

Fenning, P., Theodos, J., Benner, C., \& Bohanon-Edmonson, H. (2004). Integrating proactive discipline practices into codes of conduct. Journal of School Violence, 3(1), 45-61. https://doi.org/10.1300/J202v03n01_05

Fowler, D. (2011). School discipline feeds the "pipeline to prison". The Phi Delta Kappan, 93(2), 14-19. https://doi.org/10.1177/003172171109300204

Gerlinger, J., \& Wo, J. C. (2016). Preventing school bullying: Should schools prioritize an authoritative school discipline approach over security measures? Journal of School Violence 15(2), 133-157. https://doi.org/10.1080/15388220.2014.956321

Goodman-Scott, E. (2013). Maximizing school counselors' efforts by implementing school-wide positive behavioral interventions and supports: A case study from the field. Professional School Counseling, 17(1), 111-119. https://doi.org/10.1177/2156759X0001700106

Grandmont, R. P. (2003). Judicious discipline: A constitutional approach for public high schools. American Secondary Education, 31(3), 97-117.

Greene, R. W. (2011). Collaborative problem solving can transform school discipline. The Phi Delta Kappan, 93(2), 25-29. https://doi.org/10.1177/003172171109300206

Toward an alternative community-driven restorative model of school discipline 
Gregory, A., \& Cornell, D. (2009). “Tolerating” adolescent needs: Moving beyond zero tolerance policies in high school. Theory into Practice, 48(2), 106-113. https://doi.org/10.1080/00405840902776327

Gregory, A., Skiba, R.J., \& Noguera, P. A. (2010). The achievement gap and the discipline gap: Two sides of the same coin? Educational Researcher, 39(1), 59-68. https://doi.org/10.3102/0013189X09357621

Hamilton-Hinch, B.-A., Harkins, M. J., \& Seselja, D. (2017). Implementing culturally sensitive pedagogies. Proceedings of the Atlantic Universities' Teaching Showcase, 21, 99-114.

Hamilton-Hinch, B.-A., McIsaac, J.L., Harkins, M.J., Jarvis, S., \& LeBlanc, J.C. (2021) A call for change in the public education system in Nova Scotia. Canadian Journal of Education/Revue canadienne de l'éducation, 44(1), CI64-CI92. https://doi.org/10.53967/cje-rce.v44i1.5025

Hantzopoulos, M. (2011). Deepening democracy how one school's fairness committee offers an alternative to "discipline". Schools: Studies in Education, 8(1), 112-116. https://doi.org/10.1086/659440

Hawken, L. S., MacLeod, K. S., \& Rawlings, L. (2007). Effects of the behavior education program (BEP) on office discipline referrals of elementary school students. Journal of Positive Behavior Interventions, 9(2), 94-101. https://doi.org/10.1177/10983007070090020601

Hayle, S., Wortley, S., \& Tanner, J. (2016). Race, street life, and policing: Implications for racial profiling. Canadian Journal of Criminology and Criminal Justice, 58(3), 322-353. https://doi.org/10.3138/cjccj.2014.E32

House of Assembly Halifax. (2018). Education Act. Government of Nova Scotia.

James, C. E. (2012). Students "at risk": Stereotypes and the schooling of Black boys. Urban Education, 47(2), 464-494. https://doi.org/10.1177\%2F0042085911429084

James, C., Este, D., Bernard, W.T., Benjamin, A., Lloyd, B., \& Turner, T. (2010). Race and WellBeing: The Lives, Hopes and Activism of African Canadians. Fernwood Publishing.

Jean-Pierre, J. (2021). How African Nova Scotians envision culturally relevant and sustaining pedagogy as civic repair. British Journal of Sociology of Education, 42(8), 1153-1171. https://doi.org/10.1080/01425692.2021.1981247

Jean-Pierre, J., \& Parris-Drummond, S. (2018). Alternative school discipline principles and interventions: An overview of the literature. McGill Journal of Education/Revue des sciences de l'éducation de McGill, 53(3), 414-433. https://mje.mcgill.ca/article/view/9547

Lapan, R. T. (2012). Comprehensive school counseling programs: In some schools for some students but not in all schools for all students. Professional School Counseling, 16(2), 84-88. https://doi.org/10.1177/2156759X1201600201

Laroche, J. (2018, January 24). Nova Scotia to Dissolve Elected School Boards in Favour of Advisory Council. $C B C$. https://www.cbc.ca/news/canada/nova-scotia/nova-scotia-schoolboards-dissolve-1.4501414

Toward an alternative community-driven restorative model of school discipline 
Lee, E., \& Marshall, C. (2009). Reality Check: A review of key area in the BLAC Report for their effectiveness in enhancing the educational opportunities and achievement of African Nova Scotian learners. Enidlee Consultants Inc.

Livingstone, A-M., Celemencki, J., \& Calixte, M. (2014). Youth participatory action research and school improvement: The missing voices of Black youth in Montreal. Canadian Journal of Education/Revue canadienne de l'éducation, 37(1), 283-307. www.jstor.org/stable/canajeducrevucan.37.1.283

MacAllister, J. (2014). Why discipline needs to be reclaimed as an educational concept. Educational Studies, 40(4), 438-451. https://doi.org/10.1080/03055698.2014.930341

Maddalena, V., Bernard, W.T., Davis-Murdoch, S., \& Smith, D. (2013). Awareness of palliative care and end-of-life options among African Canadians in Nova Scotia. Journal of Transcultural Nursing, 24(2), 144-152. https://doi.org/10.1177/1043659612472190

Malinen, K, \& Roberts-Jeffers, T. (2019). Who cares? Racial identity and the family-school relationship. Race Ethnicity and Education. https://doi.org/10.1080/13613324.2019.1679756

Martin, C. (2015). Empathy, equity, empowerment: Using restorative practices to build character and community while reducing suspensions. Voices in Urban Education, 42, 14-18.

Mayer, G. R. (2001). Antisocial behavior: Its causes and prevention within our schools. Education and Treatment of Children, 24(4), 414-429. www.jstor.org/stable/42900501

Mazama, A. (2001). The afrocentric paradigm: contours and definitions. Journal of Black Studies, 31(4), 387-405. https://doi.org/10.1177/002193470103100401

McCluskey, G., Lloyd, G., Kane, J., Riddell, S., Stead, J., \& Weedon, E. (2008). Can restorative practices in schools make a difference? Educational Review, 60(4), 405-417. https://doi.org/10.1080/00131910802393456

Nasir, N. S., Ross, K. M., McKinney de Royston, M., Givens, J., \& Bryant, J. N. (2013). Dirt on my record: Rethinking disciplinary practices in an all-Black, all-male alternative class. Harvard Educational Review, 83(3), 489-543. https://doi.org/10.17763/haer.83.3.t56958753811p56t

Nielsen, L. (1979). Let's suspend suspensions: Consequences and alternatives. Personnel and Guidance Journal, 57(9), 442-445. https://doi.org/10.1002/j.2164-4918.1979.tb05432.x

Noguera, P. A. (2003). Schools, prisons, and social implications of punishment: Rethinking disciplinary practices. Theory into Practice, 42(4), 341-350. https://doi.org/10.1207/s15430421tip4204_12

Nunn, M. (2006). Spiraling Out of Control-Lessons Learned from a Boy in Trouble: Report of the Nunn Commission of Inquiry. The Nunn Commission of Inquiry.

Olley, R. I., Cohn, A., \& Cowan, K. C. (2010). Promoting safe schools and academic success: Moving your school from punitive discipline to effective discipline. Communiqué, 39(1), 7-8.

Pachai, B., \& Bishop, H. (2006). Historic Black Nova Scotia. Nimbus.

Toward an alternative community-driven restorative model of school discipline 
Province of Nova Scotia. (2015a). Provincial School Code of Conduct Policy. Nova Scotia Department of Education.

Province of Nova Scotia. (2015b). The Three R's: Renew, Refocus, Rebuild - Nova Scotia's Action Plan for Education. Nova Scotia Department of Education.

Ruck, M. D., \& Wortley, S. (2002). Racial and ethnic minority high school students' perceptions of school disciplinary practices: A look at some Canadian findings. Journal of Youth and Adolescence, 31(3), 185-195. https://doi.org/10.1023/A:1015081102189

Ryan, T. G., \& Ruddy, S. (2015). Restorative justice: A changing community response. International Electronic Journal of Elementary Education, 7(2), 253-262.

Ryan, T. G., \& Zoldy, S. (2011). Alternatives to suspension: A government initiative. International Journal of Educational Reform, 20(4), 322-342. https://doi.org/10.1177/105678791102000403

Salole, A. T., \& Abdulle, Z. (2015). Quick to punish: An examination of the school to prison pipeline for marginalized youth. Canadian Review of Social Policy/Revue canadienne de politique sociale, $72 / 73,124-168$.

Samuels-Wortley, K. (2019). Youthful discretion: Police selection bias in access to pre-charge diversion programs in Canada. Race and Justice. Advance online publication. https://doi.org/10.1177/2153368719889093

Sanders, D. (2001). A caring alternative to suspension. The Education Digest, 66, 51-54.

Saney, I. (1998). Canada: The Black Nova Scotian Odyssey: A chronology. Race \& Class, 40(1), 78-91. https://doi.org/10.1177/030639689804000107

Sehatzadeh, A. L. (2008). A retrospective on the strengths of African Nova Scotian communities: Closing ranks to survive. Journal of Black Studies, 38(3), 407-412. https://doi.org/10.1177/0021934707306574

Shirley, E. L. M., \& Cornell, D. G. (2012). The contribution of student perceptions of school climate to understanding the disproportionate punishment of African American students in a middle school. School Psychology International, 33(2), 115-134. https://doi.org/10.1177/0143034311406815

Sibblis, C. (2014). Expulsion programs as colonizing spaces of exception, Race, Gender \& Class, 21(1/2), 64-81.

Simmons, L. (2009). End of the line: Tracing racial inequality from school to prison. Race/Ethnicity, 2(2), 215-241.

Skiba, R. J., \& Losen, D. J. (2015). From reaction to prevention: Turning the page on school discipline. American Educator, 44, 4-13.

Skiba, R.J., \& Peterson, R.L. (2000). School discipline at a crossroads: From zero tolerance to early response. Exceptional Children, 635-347. https://doi.org/10.1177/001440290006600305

Toward an alternative community-driven restorative model of school discipline 
Solorzano, D.G., \& Yosso, T.G. (2002). Critical race methodology: Counter-storytelling as an analytical framework for education research. Qualitative Inquiry, 8(1), 23-44. https://doi.org/10.1177/107780040200800103

Statistics Canada. (2017). Census Profile. 2016 Statistics Canada Catalogue no 98-316X2016001. Ottawa.

$\mathrm{pd} /$ prof/index.cfm?Lang $=\mathrm{E}$

Swoszowski, N. C., Jolivette, K., \& Fredrick, L. D. (2013). Addressing the social and academic behavior of a student with emotional and behavioral disorders in an alternative setting. The Journal of Classroom Interaction, 48(1), 28-36.

Waldron, I. G. (2018). There's something in the water: Environmental racism in Indigenous and Black communities. Fernwood Publishing.

Warren, J. S., Bohanon-Edmonson, H. M., Turnbull, A. P., Sailor, W., Wickham, D., Griggs, P., $\&$ Beech, S. E. (2006). School-wide positive behavior support: Addressing behavior problems that impede student learning. Educational Psychology Review, 18(2), 187-198. https://doi.org/10.1007/s10648-006-9008-1

Williams, M. Y. (2013). African Nova Scotian restorative justice: A change has gotta come. The Dalhousie Law Journal, 36(2), 419-459.

Winton, S. (2013). From zero tolerance to student success in Ontario, Canada. Educational Policy, 27(3), 467-498. https://doi.org/10.1177/0895904812453994

Woodbury, R. (2016, December 12). African Nova Scotian students being suspended at disproportionately higher rates. $C B C$. http://www.cbc.ca/news/canada/nova-scotia/african-novascotian-students-suspension-numbers-1.3885721

Woods, R. (2008). When rewards and sanctions fail: A case study of a primary school rule-breaker. International Journal of Qualitative Studies in Education, 21(2), 181-196. https://doi.org/10.1080/09518390701868979

Wortley, S. (2019). Halifax, Nova Scotia: Street Checks Report. Nova Scotia Human Rights Commission.

Zehr, H. (2002). The little book of restorative justice: A bestselling book by one of the founders of the movement. Good Books.

Toward an alternative community-driven restorative model of school discipline 
Designed by Ken Angelo 